\title{
Effect of barnacles on the survival and growth of temperate mangrove seedlings
}

\author{
S. Satumanatpan*, Michael J. Keough \\ Department of Zoology, University of Melbourne, Parkville, Victoria 3052, Australia
}

\begin{abstract}
Loss of mangrove forests is a problem in many areas of the world, and attempts to reestablish seedlings have been hindered by slow growth rates and low seedling survival. This poor seedling performance has, in part, been attributed to the presence of barnacles attached to stems and leaves of mangroves. There is, however, little experimental evidence to assess the importance of these fouling organisms. In Western Port, a large bay in southeastern Australia, the only species of mangrove, Avicennia marina, is heavily fouled by a single barnacle species, Elminius covertus. We tested whether barnacles influenced seedling growth and survival of $A$. marina by removing them from the stem, upper, and lower leaf surfaces, in all combinations. Seedlings were then followed for 2 yr and measured at quarterly intervals. Survival of mangrove seedlings over the $2 \mathrm{yr}$ period did not depend on the presence of barnacles on any surface. Seedlings grew mainly in late spring and summer, increasing in height and number of leaves. The presence of $E$. covertus on seedlings of $A$. marina did not have a significant negative effect on their growth, although the experiment was capable of detecting subtle differences in growth with high power. It is suggested that other factors, such as a dense cover of algae or seagrasses, smothering by sediments, and damage by herbivores, as well as unfavorable climatic conditions, are stronger influences than barnacles on the survival and growth of seedlings of $A$. marina.
\end{abstract}

KEY WORDS: Mangrove - Seedling establishment - Fouling organisms - Barnacles - Temperate Australia

\section{INTRODUCTION}

Mangrove forests are important in forestry as sources of charcoal, firewood, and timber (Aksornkoae 1985. Arbhabhirama et al. 1988) and in fisheries as shelters and nurseries for young fish and crustaceans (Butler et al. 1977, Bell et al. 1984, Aksornkoae 1985, Arbhabhirama et al. 1988, Robertson \& Duke 1990). Moreover, mangroves also play an important role in stabilizing shorelines in coastal streams and estuaries by protecting them against tidal bores and soil erosion (Butler et al. 1977, Clough 1982, Arbhabhirama et al. 1988).

Throughout the tropics, mangrove forests are being removed at an increasing rate by clear-felling for production of wood chips, for the development of aquaculture ponds, or to provide land for farming, housing or

- Present address: Faculty of Environment \& Resource Studies, Mahidol University, Salaya, Nakhon Pathom 73170, Thailand.E-mail: ensnt@mahidol.ac.th tourist projects (Robertson \& Duke 1990), with up to $80 \%$ losses in some regions (Sasekumar \& Lim 1995). In Australia, most of the threats to temperate mangrove forests come from reclamation of land, changes in flow of water because of adjacent development, and pollution (Allaway 1985, Chapman \& Underwood 1995). Attempts are often made to regenerate forests or to establish mangroves in new areas, in order to compensate for the loss of habitat in other areas (Sudara et al. 1994) by transplanting seedlings. Characteristic of these attempts is the low survival of seedlings (Sudara et al. 1994, Rawangkul et al. 1995), which is also common in natural populations of some species (e.g. Avicennia marina, Clarke \& Myerscough 1993).

A wide range of factors has been suggested as important causes of seedling mortality. Physical factors, such as wave and tidal action, may carry seedlings away (Walsh 1974) or restrict their establishment (Clarke \& Hannon 1969, Clarke \& Allaway 1993, Clarke \& Myerscough 1993), and deposition of fine silt may reduce survival (Macnae 1966, 1968), possibly by 
clogging stomatal pores and reducing photosynthesis (Clarke \& Hannon 1969). Shading by larger conspecific plants can also affect seedlings, although its role is unclear-even within the same species, seedlings have been regarded as shade intolerant (Macnae 1963, 1966, 1968, Thom et al. 1975, Smith 1987a,c) and best adapted to shady conditions (Attiwill \& Clough 1980, Ball \& Critchley 1982, Clarke \& Myerscough 1993). Other plants, such as macroalgae, may also reduce the establishment of seedlings (Clarke \& Myerscough 1993).

Herbivores can also reduce survival of mangrove seedlings, although their effects are variable (MacNae 1966, 1967, Smith 1987a,b, Smith et al. 1989, Robertson 1991, Siddiqi 1995), and they appear to be of minor influence in temperate Australia (Clarke \& Myerscough 1993).

Attachment of fouling organisms, particularly barnacles, to mangrove seedlings has been suggested to be an important factor affecting survival in many areas (Macnae 1968, Saenger 1982, Peng \& Xin-Men 1983, Hutchings \& Saenger 1987, Perry 1988, Clarke \& Myerscough 1993, Sudara et al. 1994, Havanon et al. 1995. Rawangkul et al. 1995). Few of these studies included explicit comparisons between mangroves with high and low densities of barnacles (but see Perry 1988), and none included experimental tests of the effects of barnacles, so the hypothesis that barnacles have deleterious effects on mangrove seedlings should be regarded as plausible, but untested.

In eastern and southern Australia, the sole mangrove species, Avicennia marina, is colonized heavily by barnacles of a range of species, such as Elminius covertus, E. adelaidae, Balanus amphitrite and Hexaminius popeiana (Anderson et al. 1988, Ross 1992, Bayliss 1993, Coates \& Mckillup 1995, Ross 1996, Ross \& Underwood 1997). In Westernport Bay, Victoria, only 1 species, E. Covertus, grows commonly on A. marina. These barnacles occur at densities of 30 individuals $\mathrm{cm}^{-2}$ on the stems, 5 to 10 individuals $\mathrm{cm}^{-2}$ on the lower leaf surfaces and 2 to 3 individuals $\mathrm{cm}^{-2}$ on the upper leaf surfaces (Nateekanjanalarp 1997). In this study, we tested whether the survival and growth of mangrove seedlings ( $>1$ yr old) were affected by barnacles by removing $E$. covertus from different parts of seedlings. To place these results into a broader context, we also described the survival and growth of young seedlings $(<1 \mathrm{yr}$ old $)$, which had not yet acquired barnacles.

\section{METHODS}

Experiments were done at the seaward edge of mangrove forests at Rhyll Inlet, Phillip Island, Victoria,
Australia $\left(42^{\circ} 27^{\prime} \mathrm{S}\right)$, where barnacles are found in great densities. Rhyll lnlet is a sheltered inlet within a larger embayment, Westernport Bay, with a tidal range of $2.3 \mathrm{~m}$. Prevailing winds are southwesterly and the inlet is close to the southern limit of mangroves. Three study sites, separated by approximately $100 \mathrm{~m}$, were randomly selected at this inlet. They were labelled $X$, $Y$ and $Z$ here, for consistency with other work examining barnacle distributions across these forests (Nateekanjanalarp 1997). The 3 sites have moderate densities of large mangrove trees, which in southern Victoria rarely exceed $3 \mathrm{~m}$ in height. Seedlings occur in the gaps between these trees, and at the seaward fringe of the forest.

Barnacle removal experiment. Eighty older seedlings (approximately 20 to $30 \mathrm{~cm}$ height), with barnacles attached to their leaves and stems, were selected randomly at each study site. From observations of growth of newly recruited seedlings at these sites, we believe that the seedlings used in the experiment were at least 1 , and probably 2 to 3 , yr old. At each site, 10 seedlings were randomly assigned to each of 8 treatments, in which we removed barnacles from stems and upper and lower leaves of seedlings, in all combinations. The treatments that resulted are presented in Table 1.

A small knife was used to remove barnacles from the seedlings, without damage to underlying tissue. Elminius covertus has a membranous, rather than calcareous base, so barnacles came off easily. Care, however, was taken to avoid physical damage to the seedlings. The experiments were maintained for $2 \mathrm{yr}$. Treatments were monitored every $1 \frac{1}{2}$ mo during the first year (May 1995 to March 1996) and every 3 mo during the second year (April 1996 to February 1997). On each visit, the height above the sediment the level of which was stable) and the number of leaves on each seedling were recorded. All seedlings were examined

Table 1. Experimental barnacle removals. The 8 treatments are shown and the presence $(+)$ or removal $(-)$ of barnacles from stems and leaves of mangrove seedlings is indicated. Note that all seedlings were handled, including Treatment 1 , from which no barnacles were removed

\begin{tabular}{|cccc|}
\hline \multirow{2}{*}{ Treatment } & \multirow{2}{*}{ Stem } & \multicolumn{2}{c|}{ Leaves } \\
& & Upper parts & Lower parts \\
\hline 1 & + & + & + \\
2 & - & + & + \\
3 & + & - & + \\
4 & + & + & - \\
5 & + & - & - \\
6 & - & - & + \\
7 & - & + & - \\
8 & - & - & \\
\hline
\end{tabular}


carefully, and, where necessary to maintain the treatments, any new settlers were removed.

Young seedlings. Thirty young seedlings (approximately 7 to $12 \mathrm{~cm}$ height, with cotyledons attached) from each of Sites X, Y, and Z were randomly selected to estimate survival and growth in the field for $2 \mathrm{yr}$. These seedlings had arrived during the early part of 1995, and barnacles had not yet settled. The height and number of leaves were recorded for each seedling in the same way as for the older seedlings. Epibiota and drift seagrass were removed at each time of monitoring. Recruitment of seedlings occurred in 1995, but not in 1996 and 1997 .

Data analysis. All data were analyzed using SYSTAT version 6 (SPPS, Inc.).

For the barnacle removal experiment, all data were analyzed by analysis of variance, and the experimental data were analyzed with 4 -factor, mixed model analyses. The 3 barnacle removal factors, i.e. presence or absence of barnacles on the stem and upper and lower leaf surfaces, were fixed factors (each had 2 levels: removal or non-removal of barnacles). We treated the fourth factor, site, as a random factor. Interactions between sites and various barnacle removal treatments that were not significant were omitted from the analysis (using $\alpha=0.25$ as a criterion for omission). Pooling of these interaction terms resulted in an increase in the degrees of freedom for the denominator and also the power of the tests for barnacle removal (Winer et al. 1991).

We tested the effects of barnacles on the proportional survival of seedlings at the end of first year and after 2 yr. These analyses were unreplicated, as we used the proportion of the 10 seedlings in each treatment combination as the dependent variable in the analysis, leaving a single value for each experimental combination.

We analyzed growth of seedlings, i.e. changes in height and the number of leaves, in 2 ways, to compare net growth at the end of the first year and the second year and also to examine growth profiles through time in the different treatments. Changes in height and change in number of leaves during the first year and at the end of second year were analyzed by a fully factorial 4-factor mixed model ANOVA. For these analyses, we used power analysis to calculate the minimal detectable effect size (MDES) with the power fixed at $80 \%$ over the first year, between Year 1 and Year 2 and over the 2 yr. Repeated-measures ANOVA was used to test whether growth profiles of seedlings in the first year and second year differed between barnacle treatments or sites. These analyses had the same 4 factors as described above, with times as the repeated factor.

For young seedlings, data from only the first year were used in the analysis because all of the seedlings died by August 1996. A chi-squared test was used to examine the proportional survival of young seedlings among sites after the first year. Repeated-measures ANOVA was used on height and number of leaves of young seedlings to compare growth profiles between sites.

\section{RESULTS}

\section{Barnacle removal experiment}

Overall, seedlings showed a clear pattern of increase in height and number of leaves through time that was independent of the presence of barnacles (see withinsubjects interactions, Table 2). Increases in height and leaf number were greatest from late spring to early autumn (i.e. October to March). Before summer, seedlings showed little growth and the number of leaves decreased (Fig. 1). In general, any effects of barnacles were consistent across the 3 sites.

Seedlings at Site $X$ survived better than those at Sites $Y$ and $Z$ during both years (Table 3, Fig. 2). In addition, there was a strong effect of removing barnacles from the stem on the survival of seedlings in the first year (Table 3). Against expectations, seedlings with barnacles left on the stem survived better than

$\begin{array}{ll}\text { Height } & \text { No. of } \\ (\mathrm{cm}) & \text { leaves }\end{array}$

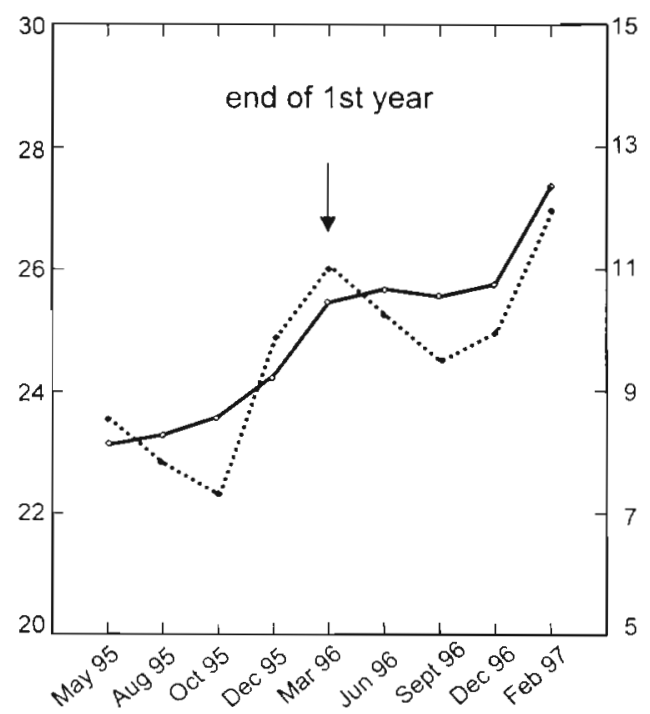

Fig. 1. Avicennia marina. Growth profile of seedlings in all treatments $(\mathrm{n}=77)$ during the 2 yr of study: (-) height and (…) number of leaves. Appropriate measure of variation is the square root of $\mathrm{MS}_{\text {error }}$ from the within-subjects part of the analysis in Table 2. For height, this pooled $\mathrm{SD}=0.89$, and for the number of leaves, pooled $\mathrm{SD}=2.47$ 
Table 2. Repeated-measures ANOVA to test the effects of site and the presence or absence of barnacles on the stem and upper and lower leaf surfaces on growth profiles (height, number of leaves) of seedlings that survived over 2 yr $(n=77)$. F-ratios, $\mathrm{p}$-values and the error mean square term used to test all effects are shown. Separate errors were used for the between subjects (i.e. time-averaged) values and the profiles over time. Significant effects are shown in bold

\begin{tabular}{|c|c|c|c|c|c|}
\hline \multirow{2}{*}{ Source } & \multirow[t]{2}{*}{ df } & \multicolumn{2}{|c|}{ Height of seedlings } & \multicolumn{2}{|c|}{ No. of leaves } \\
\hline & & $F$ & $\mathrm{p}$ & $F$ & $\mathrm{p}$ \\
\hline \multicolumn{6}{|l|}{ Between subjects (seedlings) } \\
\hline Site & 2 & 0.186 & 0.831 & 2.250 & 0.113 \\
\hline Stem & 1 & 0.220 & 0.640 & 0.562 & 0.456 \\
\hline Upper & 1 & 0.003 & 0.956 & 0.312 & 0.579 \\
\hline Lower & 1 & 0.002 & 0.963 & 1.190 & 0.279 \\
\hline Stem $\times$ Upper & 1 & 0.451 & 0.504 & 0.420 & 0.519 \\
\hline Stem $\times$ Lower & 1 & 0.163 & 0.688 & 0.402 & 0.528 \\
\hline Upper $\times$ Lower & 1 & 0.104 & 0.748 & 0.091 & 0.764 \\
\hline Stem $\times$ Upper $\times$ Lower & 1 & 0.036 & 0.850 & 1.407 & 0.240 \\
\hline $\mathrm{MS}_{\text {error }}$ & 67 & 288.570 & & 172.002 & \\
\hline \multicolumn{6}{|l|}{ Within subjects } \\
\hline Time & 8 & 105.420 & 0.000 & 11.023 & 0.000 \\
\hline Time $\times$ Site & 16 & 0.491 & 0.504 & 1.270 & 0.277 \\
\hline Time $\times$ Stem & 8 & 0.546 & 0.570 & 1.362 & 0.258 \\
\hline Time $\times$ Upper & 8 & 0.634 & 0.664 & 0.443 & 0.696 \\
\hline Time $\times$ Lower & 8 & 0.669 & 0.701 & 1.079 & 0.354 \\
\hline Time $\times$ Stem $\times$ Upper & 8 & 0.653 & 0.684 & 0.982 & 0.394 \\
\hline Time $\times$ Stem $\times$ Lower & 8 & 0.654 & 0.685 & 0.883 & 0.440 \\
\hline Time $\times$ Upper $\times$ Lower & 8 & 0.173 & 0.164 & 0.908 & 0.428 \\
\hline Time $\times$ Stem $\times$ Upper $\times$ Lower & 8 & 0.233 & 0.228 & 1.065 & 0.360 \\
\hline $\mathrm{MS}_{\text {error }}$ & 536 & 0.795 & & 6.090 & \\
\hline
\end{tabular}

Table 3. Four-factor ANOVA to test the effects of site, the presence or absence of barnacles on the stem and upper and lower leaf surfaces on proportional survival and growth of seedlings over the first year and the second year. In each analysis, all effects were tested against the error mean square. Degrees of freedom associated with this term were 14 for survival, and 165 and 67 for the 2 growth measures in the first and second years, respectively. Significant effects are shown in bold

\begin{tabular}{|c|c|c|c|c|c|c|c|}
\hline \multirow[t]{2}{*}{ Source } & \multirow[t]{2}{*}{$\mathrm{df}$} & \multicolumn{2}{|c|}{ Survival } & \multicolumn{2}{|c|}{$\begin{array}{c}\text { Change in } \\
\text { height }\end{array}$} & \multicolumn{2}{|c|}{$\begin{array}{l}\text { Change in } \\
\text { no. of leaves }\end{array}$} \\
\hline & & $F$ & $\mathrm{p}$ & $F$ & $p$ & $F$ & $\mathrm{p}$ \\
\hline \multicolumn{8}{|l|}{ First year } \\
\hline Site & 2 & 6.253 & 0.011 & 4.669 & 0.011 & 7.939 & 0.001 \\
\hline Stem & 1 & 8.423 & 0.012 & 10.413 & 0.002 & 1.215 & 0.272 \\
\hline Upper leaf & 1 & 1.143 & 0.303 & 0.169 & 0.682 & 7.219 & 0.008 \\
\hline Lower leaf & 1 & 0.583 & 0.458 & 0.183 & 0.669 & 1.588 & 0.209 \\
\hline Stem $\times$ Upper & 1 & 0.583 & 0.458 & 1.229 & 0.269 & 0.756 & 0.386 \\
\hline Stem $\times$ Lower & 1 & 0.583 & 0.458 & 0.662 & 0.417 & 2.028 & 0.156 \\
\hline Upper $\times$ Lower & 1 & 1.890 & 0.191 & 2.208 & 0.139 & 0.547 & 0.461 \\
\hline Stem $\times$ Upper $\times$ Lower & 1 & 1.143 & 0.303 & 1.199 & 0.275 & 2.365 & 0.126 \\
\hline $\mathrm{MS}_{\text {error }}$ & $14 / 165$ & 0.018 & & 0.963 & & 9.433 & \\
\hline \multicolumn{8}{|l|}{ Second year } \\
\hline Site & 2 & 46.420 & 0.000 & 1.359 & 0.264 & 2.573 & 0.084 \\
\hline Stem & 1 & 5.474 & 0.035 & 0.152 & 0.698 & 1.307 & 0.257 \\
\hline Upper leaf & 1 & 0.036 & 0.852 & 0.095 & 0.758 & 0.571 & 0.453 \\
\hline Lower leaf & 1 & 1.067 & 0.319 & 0.033 & 0.857 & 1.529 & 0.221 \\
\hline Stem $\times$ Upper & 1 & 0.427 & 0.524 & 0.040 & 0.843 & 0.181 & 0.672 \\
\hline Stem $\times$ Lower & 1 & 5.474 & 0.035 & 0.413 & 0.523 & 0.483 & 0.489 \\
\hline Upper $\times$ Lower & 1 & 2.239 & 0.157 & 1.221 & 0.273 & 0.676 & 0.414 \\
\hline Stem $\times$ Upper $\times$ Lower & 1 & 0.427 & 0.524 & 1.654 & 0.203 & 0.661 & 0.419 \\
\hline $\mathrm{MS}_{\text {error }}$ & $14 / 67$ & 0.009 & & 2.777 & & 23.479 & \\
\hline
\end{tabular}


First year
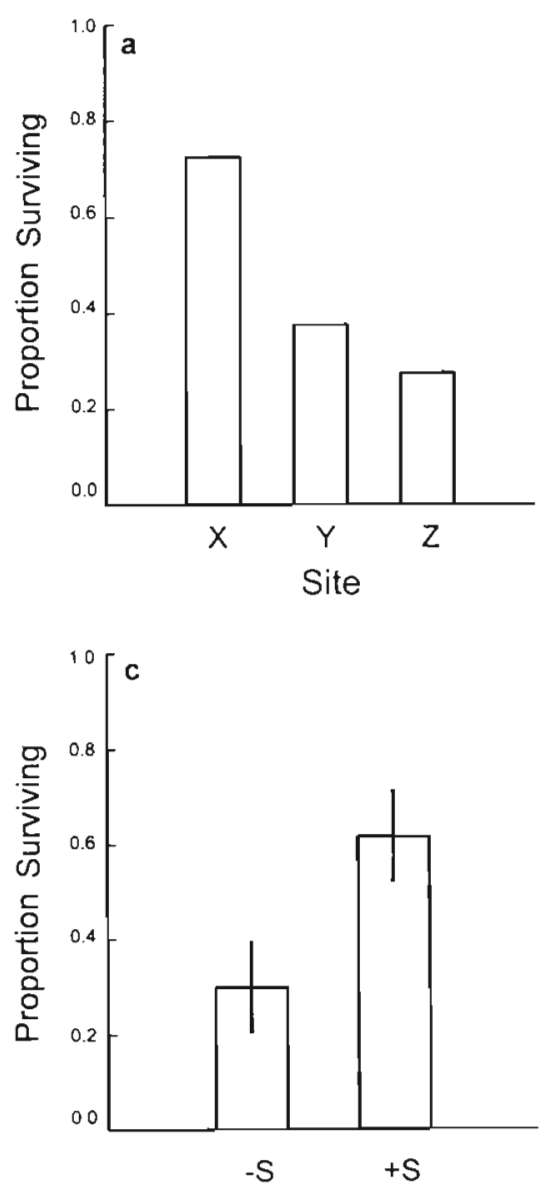

Second year
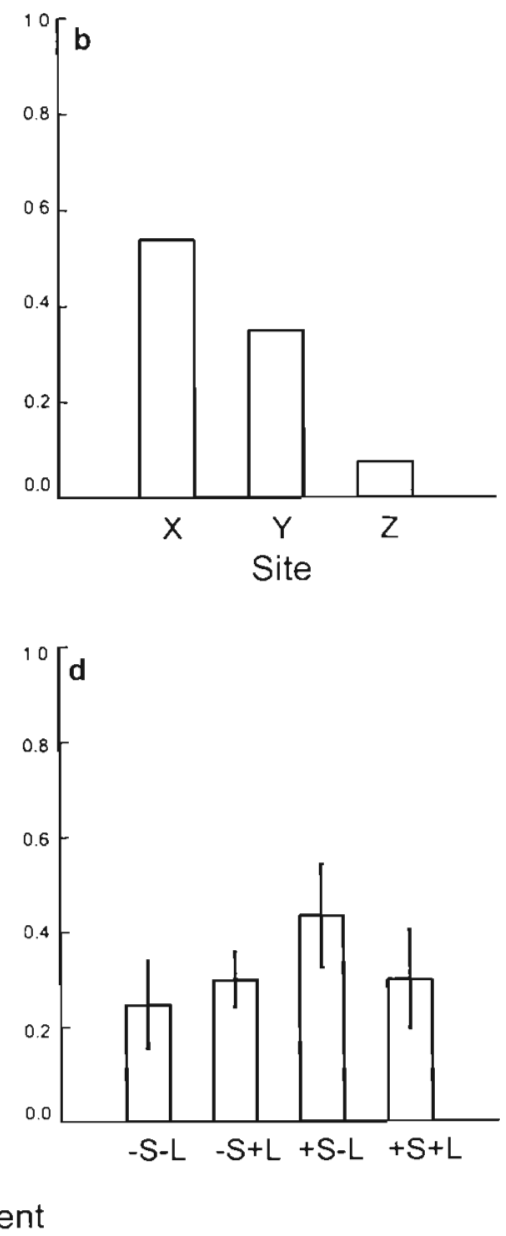

Fig. 2. Avicennia marina. Significant effects on survival of seedlings. (a, b) Proportional survival of seedlings at Sites $X, Y$ and $Z$ at the end of first and second years. (c) Overall effects of barnacles on the stem (S) in the first year. (d) Interaction between barnacle presence on stem (S) and lower-leaf surface (L). Presence or absence of barnacles is indicated by + or -

seedlings that had barnacles removed (Fig. 2). In the second year, the effect of treatments on the survival of seedlings was complex. For that year we detected a significant interaction between the effect of the presence or absence of barnacles on the stem and the presence or absence of barnacles on the lower leaf surface (Table 3, Fig. 2). Seedlings survived better if barnacles were left on the stem and removed from the lower leaf surfaces. They had the lowest survival when barnacles were removed from both areas.

Over the first year, seedlings increased in height by around $2 \mathrm{~cm}$, and with a net addition of a few leaves. Seedlings at Site $X$ grew more than seedlings at Sites $\mathrm{Y}$ and $\mathrm{Z}$ (Table 3, Fig. 3), with an increase in height approximately $5 \mathrm{~mm}$ greater than at the other sites, and added 3 new leaves, rather than 1 or 2 . Overall, seedlings with barnacles left on the stem grew taller than seedlings that had barnacles removed from the stem (Table 3, Fig. 3). Seedlings grew almost twice as many new leaves if barnacles were removed from upper leaf surfaces (Table 3, Fig. 3).

No statistically significant difference in growth (change in height or number of leaves) of seedlings was detected for any treatments over the whole $2 \mathrm{yr}$ (Table 3). The 2 significant effects seen in the first year were not detected; seedlings with barnacles on the stem had an almost identical increase in height as those where barnacles had been removed, while the effect of removing barnacles from the upper surfaces of leaves showed the same trend as in the first year, but with much greater variation (Fig. 3).

Although barnacles had no significant effect over the full experiment, our analyses had high power. We could have detected, with $80 \%$ confidence, a difference between removal treatments in the increase in height of seedlings corresponding to $3 \%$ of their 


\section{Change in Height $(\mathrm{cm})$}

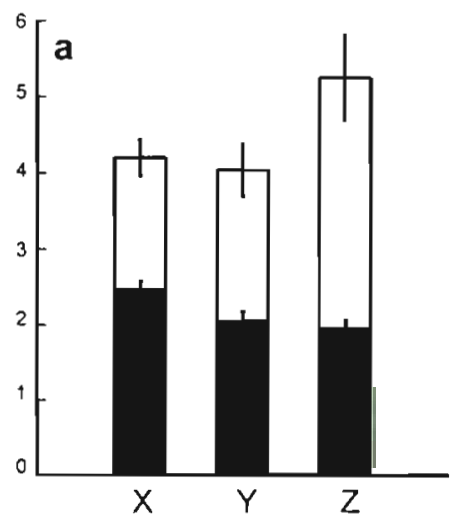

Site

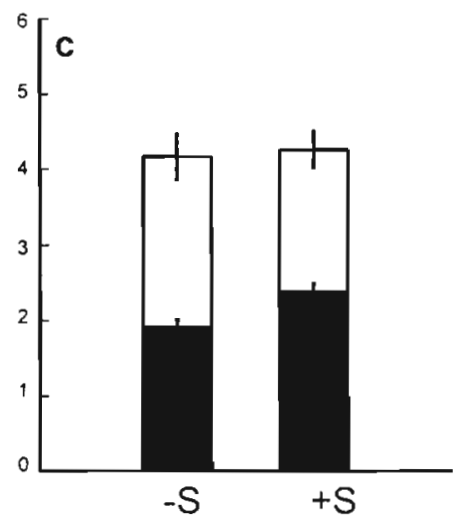

Change in

No. Leaves
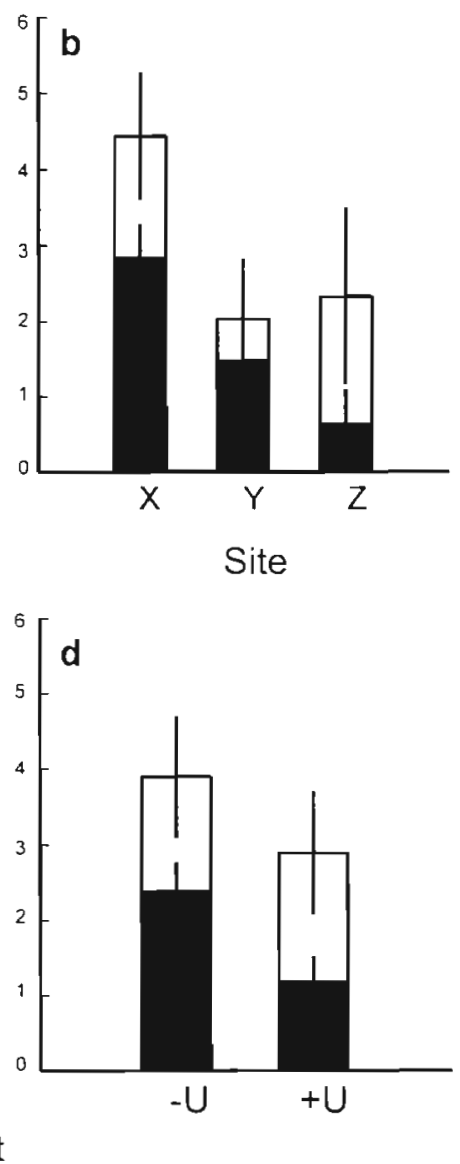

Fig. 3. Avicennia marina. Growth (mean $\pm \mathrm{SE}$ ) of seedlings over the 2 yr. Bars show changes in height and number of leaves of seedlings; shaded sections of the bars show changes during the first year: $(a, b)$ Overall growth at the 3 sites; (c, d) significant effects of barnacles. (c) Effect of barnacles on the stem (S) on change in height; (d) effects of barnacles on the upper surface of leaves (U) on changes in the number of leaves. Presence or absence of barnacles is indicated by + or -

height, between Year 1 and Year 2, and a $26 \%$ change in the rate of production of new leaves. Over the full 2 yr, we could have detected a $5 \%$ increase in growth rate, as measured by height, and a $42 \%$ change in number of leaves (Table 4).

Overall, seedlings in all 3 sites increased in height between November 1995 and March 1996 (late spring through summer) (Table 5, Fig. 4), and had broadly similar growth profiles. Seedlings that had barnacles removed from the stem did not increase in height as much as those retaining barnacles, especially between November 1995 and March 1996 (Fig. 4). Leaf number was affected by an interaction between time and site during the first-year study (Table 5). However, the general patterns of leaf number across time on each site were similar (Fig. 5). In general, the number of leaves on seedlings decreased consistently on all sites from the beginning of the experiment in May 1995 through to October 1995. Leaf numbers then started to increase in November 1995 before decreasing again in January 1996 (Fig. 5). Although there was a significant interaction between time and the presence or absence of barnacles on upper leaf surfaces, the general profile of leaf number across time was similar for each of these treatments (Fig. 5). A similar result was observed for an interaction between time and the presence or absence of barnacles on lower leaf surfaces (Fig, 5).

When the growth profiles were followed for $2 \mathrm{yr}$, we found no significant effect of the presence of barnacles in any combination (Table 2). 


\section{Young seedlings}

The survival of young seedlings in the field was not significantly different among sites at the end of the first year $\left(\chi^{2}=2\right.$, df $=2, p=0.368$, Fig, 6), with 40 to $70 \%$ mortality. All of the seedlings died after August 1996.

Seedlings that survived to August 1996 did not grow much between May 1995 and November 1995, but grew during the summer. In the following autumn and winter, seedlings showed little increase in height, and the number of leaves decreased. These seedlings were approximately $9 \mathrm{~cm}$ high when first recorded, with an average 4 to 5 leaves (Fig. 7 ). In the first year after

Table 4. Minimal detectable effect size (MDES) of change in height and number of leaves of seedlings at $80 \%$ power.

Effect sizes are expressed as absolute values, and as percentages of the mean value for seedlings without barnacles

\begin{tabular}{|c|c|c|c|c|}
\hline \multirow[t]{2}{*}{ Time } & \multicolumn{2}{|c|}{$\begin{array}{l}\text { Change in } \\
\text { height }(\mathrm{cm})\end{array}$} & \multicolumn{2}{|c|}{$\begin{array}{c}\text { Change in no. } \\
\text { of leaves }\end{array}$} \\
\hline & MDES & $\%$ & MDES & $\%$ \\
\hline Year 1 & 0.430 & 1.91 & 1.344 & 16.76 \\
\hline Year $1-$ Year 2 & 0.799 & 3.16 & 2.724 & 25.63 \\
\hline Year 2 & 1.149 & 5.09 & 3.341 & 41.67 \\
\hline
\end{tabular}

establishment, they grew approximately $2 \mathrm{~cm}$, and the number of leaves increased to 6 to 7 (Fig. 7). Their overall growth was similar to that of older seedlings. Growth was heterogeneous between sites; seedlings at Site $Y$ increased in height more than those at Sites $X$ and $Z$, causing a significant interaction between site and time (Table 6, Fig. 7). Leaf production did not differ between sites (Table 6)

\section{DISCUSSION}

Elminius covertus had no major negative effect on the survival and growth of seedlings of Avicennia marina at Rhyll Inlet, in contrast to claims made for other mangrove systems. We did find some effects of barnacles on seedling growth and survival during the first year of the experiment, but when viewed over the whole 2 yr, barnacles had little impact.

Significant effects of barnacles occurred erratically. When barnacles were on the stem, seedlings initially survived and grew better, while removal of barnacles from upper surfaces of leaves initially allowed seedlings to add more new leaves. However, during the second year the only effect of barnacles was that seedlings survived better when barnacles were left on the stem, but re-

Table 5. Repeated-measures ANOVA to test the effects of site, the presence or absence of barnacles on the stem and upper and lower leaf surfaces on growth profiles (height, number of leaves) of seedlings in the first year ( $n=175$ ). F-ratios and p-values plus the error mean square term used to test all effects are shown. Separate errors were used for the between subjects (i.e. timeaveraged) values and the profiles over time. Significant effects are shown in bold

\begin{tabular}{|c|c|c|c|c|c|}
\hline \multirow[t]{2}{*}{ Source } & \multirow[t]{2}{*}{ df } & \multicolumn{2}{|c|}{ Height of seedlings } & \multicolumn{2}{|c|}{ No. of Leaves } \\
\hline & & $F$ & $\mathrm{p}$ & $F$ & $\mathrm{p}$ \\
\hline \multicolumn{6}{|l|}{ Between subjects (seedlings) } \\
\hline Site & 2 & 1.301 & 0.275 & 5.765 & 0.004 \\
\hline Stem & 1 & 0.349 & 0.555 & 0.851 & 0.358 \\
\hline Upper & 1 & 3.387 & 0.068 & 0.066 & 0.798 \\
\hline Lower & 1 & 0.045 & 0.832 & 0.012 & 0.914 \\
\hline Stem $\times$ Upper & 1 & 1.949 & 0.165 & 1.350 & 0.247 \\
\hline Stem $\times$ Lower & 1 & 3.754 & 0.054 & 0.405 & 0.525 \\
\hline Upper $\times$ Lower & 1 & 0.060 & 0.807 & 1.004 & 0.318 \\
\hline Stem $\times$ Upper $\times$ Lower & 1 & 1.091 & 0.298 & 4.402 & 0.037 \\
\hline $\mathrm{MS}_{\text {error }}$ & 165 & 282.767 & & 145.028 & \\
\hline \multicolumn{6}{|l|}{ Within subjects } \\
\hline Time & 8 & 428.632 & 0.000 & 139.342 & 0.000 \\
\hline Time $\times$ Site & 16 & 3.619 & 0.002 & 3.387 & 0.002 \\
\hline Time $\times$ Stem & 8 & 7.793 & 0.000 & 1.985 & 0.108 \\
\hline Time $\times$ Upper & 8 & 0.329 & 0.787 & 2.598 & 0.046 \\
\hline Time $\times$ Lower & 8 & 0.737 & 0.520 & 4.249 & 0.004 \\
\hline Time $\times$ Stem $\times$ Upper & 8 & 1.487 & 0.220 & 0.574 & 0.650 \\
\hline Time $\times$ Stem $\times$ Lower & 8 & 0.618 & 0.590 & 1.874 & 0.126 \\
\hline Time $\times$ Upper $\times$ Lower & 8 & 1.670 & 0.177 & 0.622 & 0.617 \\
\hline Time $\times$ Stem $\times$ Upper $\times$ Lower & 8 & 0.845 & 0.462 & 1.862 & 0.128 \\
\hline $\mathrm{MS}_{\text {error }}$ & 1320 & 0.235 & & 2.714 & \\
\hline
\end{tabular}


moved from lower leaf surfaces. We can think of no mechanism that could explain such an effect.

Some authors have suggested that the attachment of barnacles may reduce growth of mangrove trees in
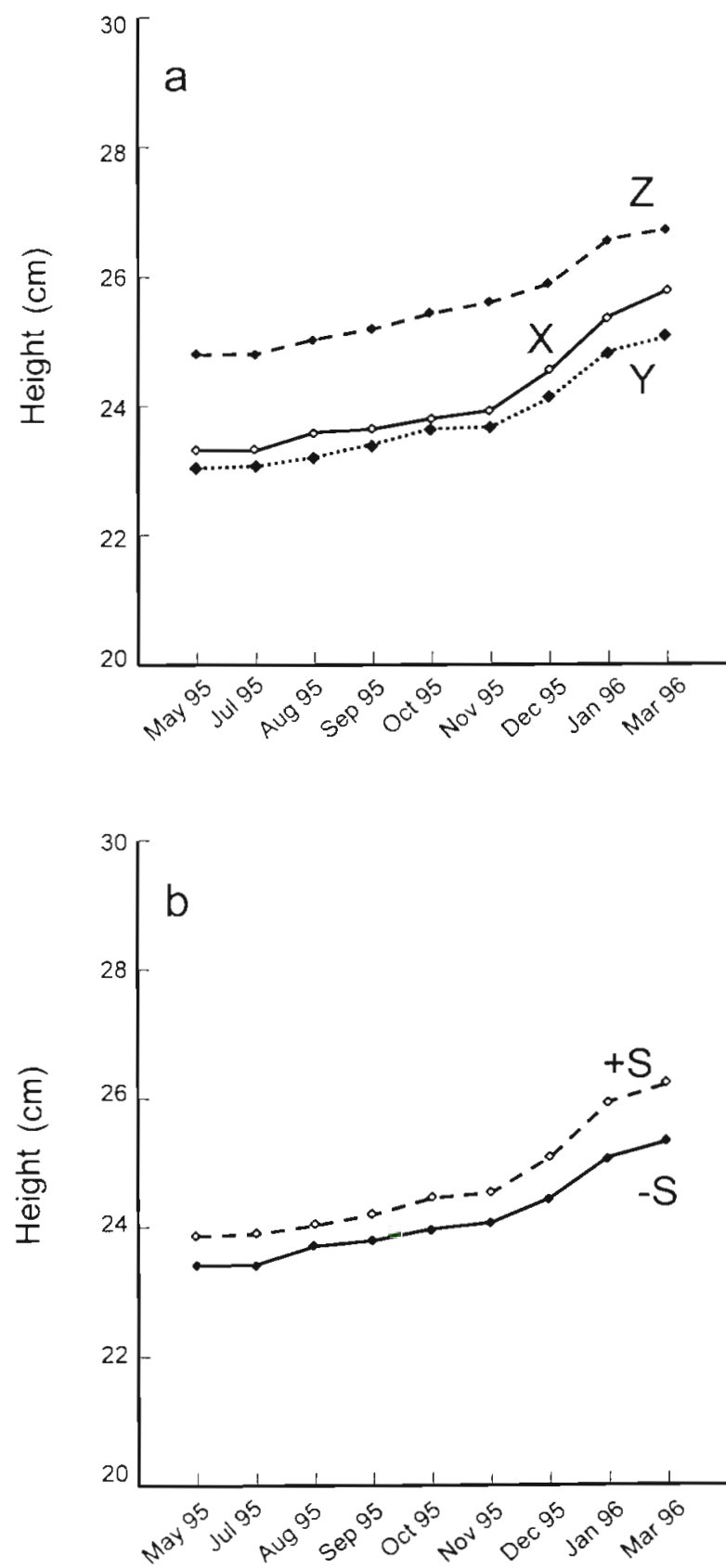

Time

Fig. 4. Avicennia marina. Profiles of height of seedlings during the first year (a) at each site and (b) on treatments with barnacles present $(+S)$ or absent $(-S)$ on the stem. The appropriate measure of variation is the square root of the $\mathrm{MS}_{\text {error }}$ for the within-subjects part of analysis in Table 5, which gives a pooled $S D=0.48$
China (Peng \& Xin-Men 1983), and mangrove seedlings in Thailand (Sudara et al. 1994, Rawangkul et al. 1995) and in more northern latitudes of Australia (Clarke \& Myerscough 1993). However, even our initial results are inconsistent with this suggestion. Even though we obtained significant results in the first year, the major effect was a positive effect of barnacles when present on the stems of seedlings.

The density of barnacles on Avicennia marina seedlings at Rhyll Inlet was within the range reported for other studies, with approximately 330 individuals per seedling for a seedling approximately height $20 \mathrm{~cm}$ and stem diameter $0.5 \mathrm{~cm}$ (Nateekanjanalarp 1997). These other studies, however, were concerned with different species of barnacles, in particular Balanus spp., which have calcareous bases for attachment. These barnacles may be more damaging to plants than the membranous base of Elminius covertus. In addition, some of these Balanus spp. grow larger than $E$. covertus, and may exert more drag and have greater mass to weigh down the leaves and branches of seedlings. Our study differs from the others in at least 2 other respects. We studied a temperate, rather than tropical or sub-tropical, mangrove system, and we used a field experiment to identify the impacts of barnacles. Therefore, we cannot determine whether this mangrove-barnacle system is different from others described in the literature, or whether the experimental approach gives a clearer view of the mangrove-barnacle interaction. Experimental studies of other systems, especially those in which balanoid barnacles are dominant, would seem a valuable avenue for investigation.

Although barnacles had little effect on growth and survival of mangrove seedlings, there was considerable mortality. All of a group of 90 newly established seedlings died within the first 18 mo of establishment, and our experimental seedlings, which we believed to be 2 to 3 yr old, suffered 60 to $70 \%$ mortality over $2 \mathrm{yr}$. Other potential factors such as a dense cover of algae, seagrasses, and sediment may kill seedlings at Rhyll Inlet. We saw a dense cover of drift algae on seedlings of Avicennia marina between August and October during in 1995 and 1996. Also, more algae were generally observed at Site $Z$ than other sites, and could explain the relatively lower survival of seedlings at this site. Presumably, algae could clog stomatal pores and reduce photosynthesis, similar to the effect of sediment coverage (Clarke \& Hannon 1969), as well as reduce light intensities. Low temperature and especially frosts are possible causes of mortality of mangroves around Westermport Bay (Westermport Bay Environmental Study 1974) and may have had a considerable effect on the survival of $A$. marina in mangrove forests at Rhyll Inlet. In addition, strong wind and wave action may also reduce the 

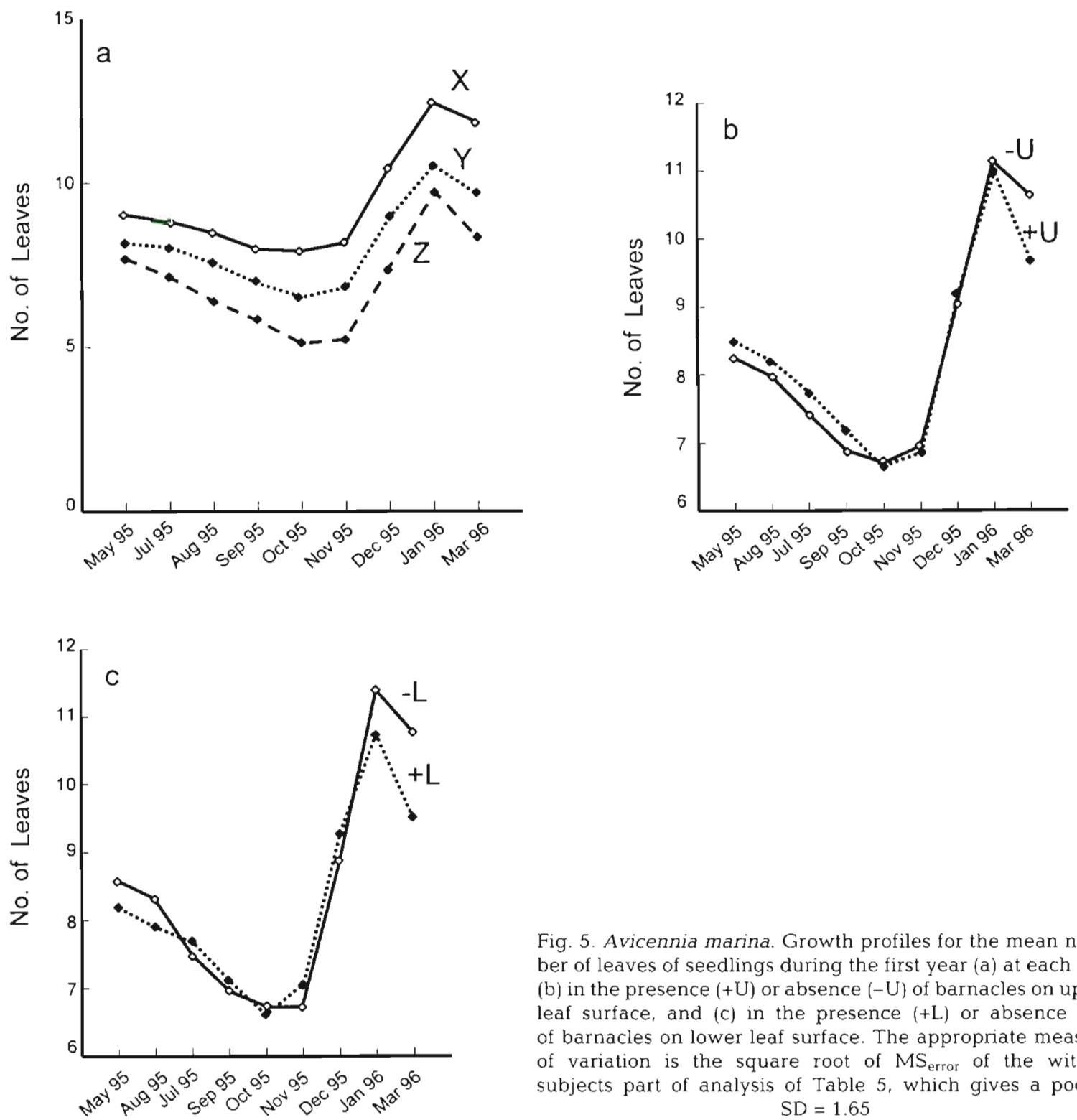

Fig. 5. Avicennia marina. Growth profiles for the mean number of leaves of seedlings during the first year (a) at each site, $(b)$ in the presence $(+U)$ or absence $(-U)$ of barnacles on upper leaf surface, and (c) in the presence $(+L)$ or absence $(-L)$ of barnacles on lower leaf surface. The appropriate measure of variation is the square root of $\mathrm{MS}_{\text {error }}$ of the withinsubjects part of analysis of Table 5 , which gives a pooled $\mathrm{SD}=1.65$

survival of seedlings (Clarke \& Allaway 1993; Clarke \& Myerscough 1993).

Herbivores such as crabs, insects, fish and snails affect the survival of mangrove seedlings in many tropical areas (e.g. Smith 1987 a,b, Robertson 1991). At Rhyll Inlet, damage by insects was common on mature mangroves (Nateekanjanalarp pers. obs.) and some evidence of herbivory by both fish and insects was seen on some seedlings (Nateekanjanalarp pers. obs.) Hence, these herbivores may play a part in seedling mortality. Other herbivores such as crabs and snails appeared unlikely to affect the survival of seedlings of Avicennia marina at all our study sites, because we saw no clear evidence of such damage in this study.
All seedlings, whether newly established or a few years old, grew relatively slowly, increasing in height by only a few cm annually, and adding few new leaves. These growth rates are much lower than reported for Avicennia marina seedlings that grew about $8 \mathrm{~cm}$ in 15 mo on the east coast of Australia (Clarke \& Allaway 1993). The mortality of seedlings at Rhyll Inlet also seems higher than for other populations of A. marina (Clarke \& Myerscough 1993). The slow growth rate of these seedlings may be because the mangrove population at Rhyll Inlet is close to the southern limit of the distribution of A. manna. With such slow growth rates, seedlings would be expected to remain at a vulnerable size for many years. This may contribute to higher mor- 


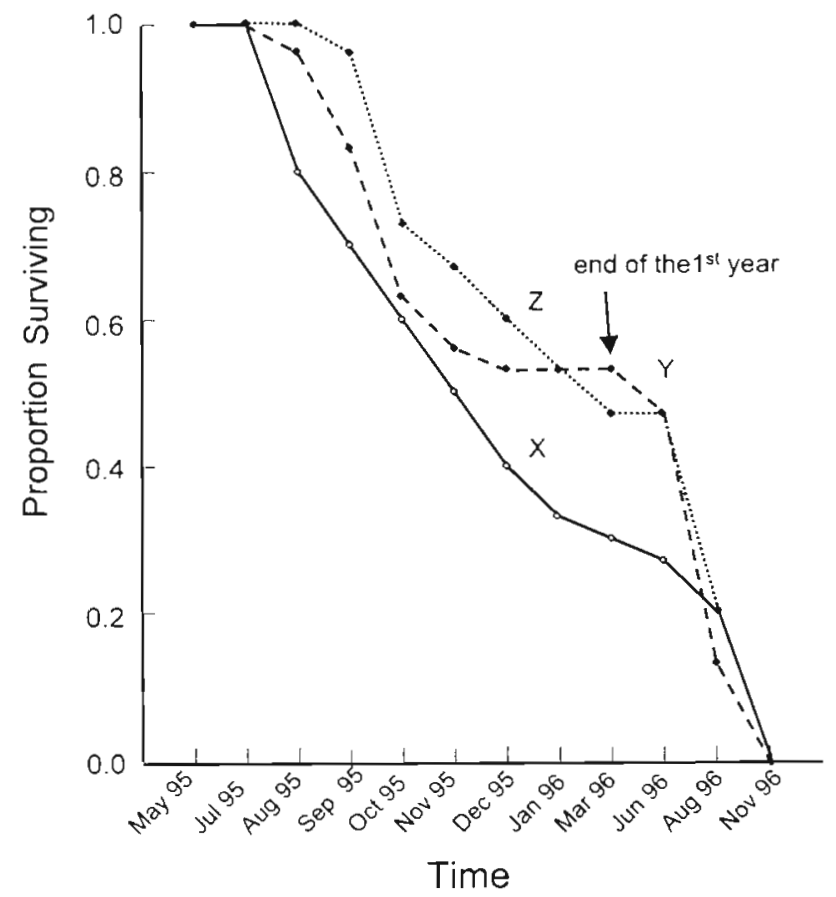

Fig. 6. Avicennia marina. Proportional survival of young seedlings at each site from May 1995 to November 1996

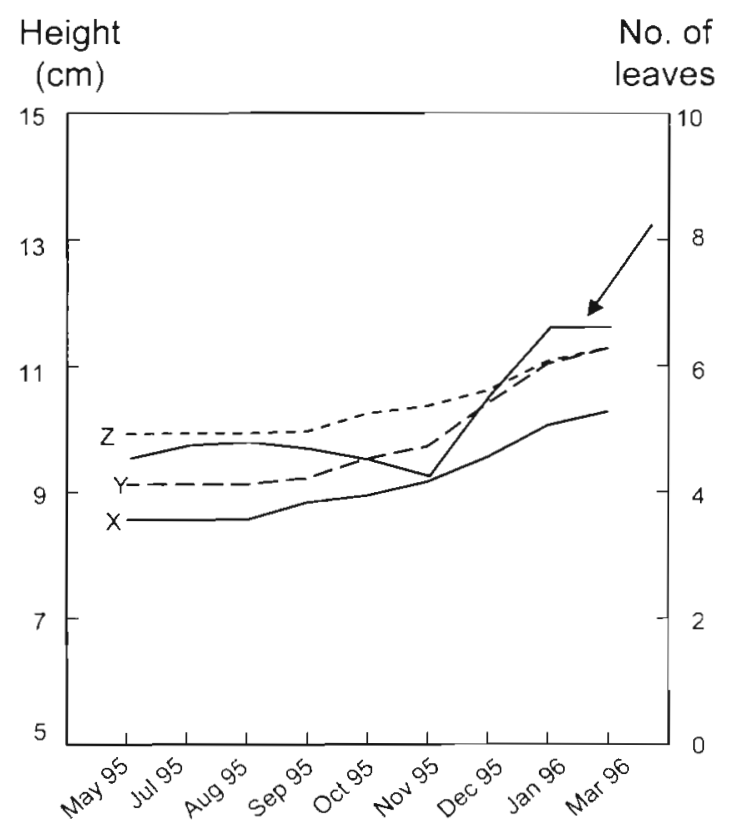

Fig. 7. Avicennia marina. Growth (mean $\pm \mathrm{SE}$ ) of young seedlings at each site at the end of first year, showing height of seedlings at each site and mean number of leaves, pooled across sites (solid line indicated by arrow). The appropriate measure of variation is the square root of within-subjects part of the analysis of Table 6 , giving a pooled $\mathrm{SD}=0.43$ for height of seedlings and 1.12 for the number of leaves
Table 6. Repeated-measures ANOVA to test the effect of site on growth profiles (height and number of leaves) of young seedlings in the first year. Significant effects are shown in bold

\begin{tabular}{|lrrrr}
\hline Source & df & MS & $F$ & $\mathrm{p}$ \\
\hline Height & & & & \\
Between subjects & & & & \\
$\quad$ Site & 2 & 34.564 & 0.986 & 0.383 \\
$\quad$ Error & 36 & 35.056 & & \\
Within subjects & & & & \\
Time & 8 & 16.140 & 87.926 & $-\mathbf{0 . 0 0 0}$ \\
$\quad$ Time $\times$ Site & 16 & 0.561 & 3.056 & $\mathbf{0 . 0 3 5}$ \\
$\quad$ Error & 288 & 0.184 & & \\
& & & & \\
Number of leaves & & & & \\
Between subjects & & & & \\
$\quad$ Site & 2 & 5.196 & 0.397 & 0.675 \\
$\quad$ Error & 36 & 13.085 & & \\
$\quad$ Within subjects & & & & \\
$\quad$ Time & 8 & 31.334 & 24.858 & $\mathbf{0 . 0 0 0}$ \\
$\quad$ Time $\times$ Site & 16 & 1.435 & 1.138 & 0.345 \\
$\quad$ Error & 288 & 1.261 & & \\
\hline
\end{tabular}

talities during the seedling stage. Although we followed seedlings of 2 age classes for $2 \mathrm{yr}$, average longer term study of seedling dynamics would be extremely valuable.

Acknowledgements. We thank Rachael Allan, Mike Holloway, Mark Norman, Theo Evans, Bron Burton, Somchai Satumanatpan, and Sigit Santaso for help in the field. This study was supported by a Melbourne University Postgraduate Scholarship (MUPS) and an Overseas Postgraduate Research Scholarship (OPRS) to S.S.

\section{LITERATURE CITED}

Aksornkoae S (1985) Traditional uses of the mangrove in Thailand. In: Field CD, Dartnall AJ (eds) Mangrove ecosystems of Asia and the Pacific. Status, exploitation and management. Proceedings of the Research for Development Seminar. Australian Institute of Marine Science, Townsville, p 104-113

Allaway WG (1985) Exploitation and destruction of mangroves in Australia. In: Field CD, Dartnall AJ (eds) Mangrove ecosystems of Asia and the Pacific. Status, exploitation and management. Proceedings of the Research for Development Seminar. Australian Institute of Marine Science, Townsville, p 183-192

Anderson DT, Anderson JT, Egon EA (1988) Balanoid barnacles of the genus Hexaminius (Archaeobalanidae: Elmininae) from mangrove of NSW, including a description of a new species. Rect Aust Mus 40:205-223

Arbhabhirama $A$, Phantumvanit $D$, Elkington $J$, Ingkasuwan $P$ (1988) Thailand natural resources profile. Oxford University Press, Singapore

Attiwill PM, Clough BF (1980) Carbon dioxide and water vapour exchange in the white mangrove. Photosynthetica $14(1): 40-47$ 
Ball MC, Critchley C (1982) Photosynthetic responses to irradiance by the grey mangrove, Avicennia marina, grown under different light regimes. Plant Physiol 70:1101-1106

Bayliss DE (1993) Spatial distribution of Balanus amphitrite and Elminius adelaidae on mangrove pneumatophores. Mar Biol 116:251-256

Bell JD, Pollard DA, Burchmore IJ, Pease BC, Middleton MJ (1984) Structure of a fish community in a temperate tidal mangrove creek in Botany Bay, New South Wales. Aust J Mar Freshw Res 35:33-46

Butler AJ, Depers AM, McKillup SC, Thomas DP (1977) Distribution and sediments of mangrove forests in south Australia. Trans R Soc S Aust 101:35-44

Chapman MG, Underwood A.J (1995) Mangrove forests. In: Underwood AJ, Chapman MJ (eds) Coastal marine ecology of temperate Australia. UNSW Press, Sydney, $p$ $187-204$

Clarke PJ, Allaway WA (1993) The regeneration niche of the grey mangrove (Avicennia marina): effects of salinity, light and sediment factors on establishment, growth and survival in the field. Oecologia 93:548-556

Clarke LD, Hannon NJ (1969) The mangrove swamp and salt marsh communities of the Sydney district. II. The holoccoenotic complex with particular reference to physiography. J Ecol 57:213-234

Clarke LD, Hannon NJ (1971) The mangrove swamp and salt marsh communities of the Sydney district. IV. The significance of species interaction. J Ecol 59:535-553

Clarke PJ, Myerscough PJ (1993) The intertidal distribution of the grey mangrove Avicennia marina in southeastern Australia: the effects of physical conditions, interspecific competition, and predation on propagule establishment and survival. Aust J Ecol 18:307-315

Clough BF (1982) Resource stability and management. In: Clough BF (ed) Mangrove ecosystems in Australia. Structure, function and management. ANU Press, Canberra, $p$ 263-264

Coates M, McKillup SC (1995) Role of recruitment and growth in determining the upper limit of distribution of the intertidal barnacle Hexaminius popeiana. Mar Freshw Res 46:1065-1070

Havanon S, Chukwamdee J, Anunsiriwat A, Meepol W (1995) Study on mangrove forest structure at Samut Songkram Province. In: The ninth national seminar on mangrove ecology, mangrove conservation for Thai society in the next decade, National Research Council of Thailand, Bangkok; Pap No. III-02

Hutchings P, Saenger P (1987) Ecology of mangroves. University of Queensland Press, Queensland

Macnae W (1963) Mangrove swamps in south Africa. J Ecol $51(1): 1-25$

Macnae W (1966) Mangrove in eastern and southern Australia. Aust J Bot 14:67-104

Macnae W (1967) Zonation within mangroves associated with estuaries in north Queensland. In: Lauff GH (ed) Estuaries. American Association for the Advancement of Science, Washington, DC, p 432-441

Macnae W (1968) A general account of the fauna and flora of mangrove swamps and forests in the Indo-West-Pacific region. Adv Mar Biol 6:73-270

Nateekanjanalarp S (1997) Ecological studies of barnacles in temperate mangrove forests. PhD thesis, University of Melbourne

Peng L, Xin-Men W (1983) Ecological notes on the mangroves of Fujian, China. In: Teas HJ (ed) Biology and ecology of mangroves. Dr W Junk Publishers, The Hague, p 31-36
Perry MD (1988) Effects of associated fauna on growth and productivity in the red mangrove. Ecology 69(4): $1064-1075$

Rawangkul S, Angsupanich S, Panitchart S (1995) Preliminary study of barnacles damaging the mangrove plantation Rhizophora mucronata at Tha Phae canal, Nakorn Si Thammarat. In: The ninth national seminar on mangrove ecology, mangrove conservation for Thai society in the next decade, National Research Council of Thailand Bangkok; Pap No. III-06

Robertson AI (1991) Plant-animal interactions and the structure and function of mangrove forest ecosystems. Aust $\mathrm{J}$ Ecol 16:433-443

Robertson AI, Duke NC (1990) Mangrove fish-communities in tropical Queensland, Australia: spatial and temporal patterns in densities, biomass and community structure. Mar Biol 104:369-379

Ross PM (1992) The ecology of barnacles in temperate mangrove forests. PhD thesis, University of Sydney

Ross PM (1996) Differences in morphology and reproduction of the barnacles Elminius covertus and Hexaminius spp. from mangrove forests in the Sydney region of New South Wales. Mar Freshw Res 47:715-721

Ross PM, Underwood A.J (1997) The distribution and abundance of barnacles in a mangrove forest. Aust J Ecol 22: $37-47$

Saenger P (1982) Morphological, anatomical and reproductive adaptations of Australian mangroves. In: Clough BF (ed) Mangrove ecosystems in Australia. Structure, function and management. ANU Press, Canberra, p 153-191

Sasekumar A, Lim KH (1995) Compatible activities and mangrove forests. In: Wilkinson CR, Sudara S, Chou LM (eds) Proceedings of the third ASEAN-Australia symposium on living coastal resources. Chulalongkorn University Press, Bangkok, p 101-104

Siddiqi AN (1995) Role of crabs in the natural regeneration of mangroves in the Sundarbans forest of Bangladesh. Aust J Ecol 20:340-343

Smith TJ (1987a) Effects of seed predators and light level on the distribution of Avicennia marina (Forsk.) Vierth. in tropical tidal forests. Estuar Coast Shelf Sci 25:43-51

Smith TJ (1987b) Seed predation in relation to tree dominance and distribution in mangrove forests. Ecology 68(2): $266-273$

Smith TJ (1987c) Effects of light and intertidal position on seedlings and growth in tropical tidal forests. J Exp Mar Biol Ecol 110:133-146

Smith TJ, Chan HT, McIvor CC, Robblee MB (1989) Comparisons of seed predation in tropical, tidal forests from three continents. Ecology 70(1):146-151

Sudara S, Nateekanjanalarp S, Ratanapongtara P (1994) Successful techniques in mangrove planting. In: Wilkinson CR, Sudara S, Chou LM (eds) Proceedings of the third ASEAN-Australia symposium on living coastal resources. Chulalongkorn University Press, Bangkok, p 377-381

Thom BG, Wright LD, Coleman JM (1975) Mangrove ecology and deltalic-estuarine geomorphology: Cambridge Gulford river, Western Australia. J Ecol 63:203-232

Walsh GE (1974) Mangroves: a review. In: Reimold RJ, Queen WH (eds) Ecology of halophytes. Academic Press, New York, p 51-174

Westernport Bay Environmental Study (1974) Possible causes of mortalities of mangrove at Crib Point, Westernport Bay. Ministry for Conservation Victoria, Melbourne

Winer BJ, Brown DR, Michels KM (1991) Statistical principles in experimental design. McGraw-Hill, New York

Submitted: October 28, 1997; Accepted: January 28, 1999

Proofs received from author(s): May 3, 1999 